\title{
Atualidade da noção de América Latina: diálogo crítico com Leslie Bethell
}

\author{
Fabio Luis Barbosa dos Santos ${ }^{1}$
}

\begin{abstract}
Resumo: tomando como ponto de partida o texto de Leslie Bethell, O Brasil e a ideia de 'América Latina' em perspectiva histórica (BETHELL, 2009), este artigo pretende colaborar para restituir a densidade política da noção de América Latina no século XXI, em particular para os brasileiros. Para concretizar este objetivo, o texto realiza o seguinte movimento: inicialmente, é resgatado o contexto político e ideológico na origem do termo. A seguir, procura-se delinear os marcos gerais que balizam a evolução histórica de projetos identificados com este conceito, até analisar duas iniciativas de integração regional em curso que calçam a argumentação de Bethell, e não tem o subcontinente como referência. Finalmente, discutimos a atualidade política e ideológica da ideia de América Latina no Brasil. Nossa hipótese é que a pertinência desta noção está relacionada, por um lado, a uma apreciação da natureza dos nexos entre esta região e os Estados Unidos no mundo contemporâneo e, por outro, às premissas políticas que orientam o horizonte civilizatório que se projeta para o Brasil.
\end{abstract}

Palavras-chave: América Latina; pensamento latino-americano; integração regional;

\section{Relevance of Latin America today: a critical dialogue with Leslie Bethell}

\begin{abstract}
Taking as a point of departure Leslie Bethell's article O Brasil e a ideia de 'América Latina' em perspectiva histórica, this essay intends to colaborate to reassert the political density of the notion of Latin America in the 21st century, particularly among Brazilians, associating it to the pursuit of continental integration as a historical necessity. With that aim, the text undertakes the following movement: at first, the political and ideological context at the origins of this notion are restated. Then, we sketch the general guidelines that bound the historical evolution of projects identified with this concept, until we analyse two ongoing regional integration iniciatives that sustain Bethell's argument, and that have not the subcontinent as a reference. Next, I discuss the political and ideological relevance of the idea of Latin America in Brasil at the present time. I suggest that the pertinence of this notion is referred, on one hand, to an aknowledgment of the particularity of the relation between this region and the United States in the contemporary world, and in the other hand, to the political premises that guide the projected historical horizon to Brazil and the region.
\end{abstract}

Keywords: Latin America; Regional Integration; Latin American thought;

Artigo recebido em: 15/02/2016

Artigo aprovado para publicação em: 20/05/2016

\footnotetext{
${ }^{1}$ Doutor em História Econômica pela Universidade de São Paulo (USP). Professor do Departamento de Relações Internacionais da Universidade Federal de São Paulo (UNIFESP). Email: faboroso@gmail.com
}

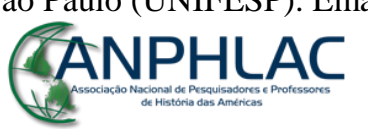

Revista Eletrônica da ANPHLAC, ISSN 1679-1061, №. 21, p. 261-297, Jul./Dez., 2016.

http://revista.anphlac.org.br 


\section{Introdução}

Questionar o estatuto político e cultural da América Latina não é uma novidade, como denunciam as linhas iniciais do ensaio de autoria do poeta e crítico literário cubano Fernández Retamar escrito em 1971, Caliban (FERNÁNDEZ RETAMAR, 2004). Ao longo do século XX, alguns dos intelectuais mais criativos do continente se debruçaram sobre esta problemática, que teve como principal expoente nos campos da filosofia e da história das ideias o mexicano Leopoldo Zea (ZEA, 1976; 1986; 1993). A novidade é ver um historiador inglês decretar a inutilidade do conceito, o que talvez gerasse pouca repercussão não fosse o fato de que este acadêmico organizou uma obra de referência sobre a área: a História da América Latina editada pela Universidade de Cambridge, traduzida para o castelhano e o português, e indicada como referência bibliográfica em cursos superiores sobre o tema ao redor do mundo (BETHELL, 1990-1996; BETHELL, 1997-2009). A pedra angular do raciocínio apresentado pelo professor para desmontar o conceito é defender a impertinência de considerar o Brasil como parte da região no século XXI, o que instiga brasileiros que pensem o contrário a se manifestarem.

Em seu texto $O$ Brasil e a ideia de 'América Latina' em perspectiva histórica, publicado no país em 2009, o historiador inglês Leslie Bethell inicialmente reconstitui a construção da ideia de América Latina no século XIX. A seguir, o autor mostra que os hispanoamericanos não integravam o Brasil em suas discussões, assim como os brasileiros tampouco se enxergavam como partícipes de projeções de unidade continental. Bethell argumenta que é somente após a Segunda Guerra que se gesta no país a percepção de uma identidade latinoamericana. Em um raciocínio análogo ao que John Phelan construiu sobre a afirmação da América Latina como uma denominação continental, visão que comentarei logo mais, o historiador inglês sugere que o motor desta mudança de percepção não seria endógeno, mas radica em alterações na formulação da política externa dos Estados Unidos, que passam a encarar o continente desta maneira. Bethell encerra seu texto indicando que, pela primeira vez em sua história, a política externa brasileira tem como foco a América do Sul (mas não a

\section{GANPHLAC}

Revista Eletrônica da ANPHLAC, ISSN 1679-1061, №. 21, p. 261-297, Jul./Dez., 2016.

http://revista.anphlac.org.br 
América Latina), interpretada como um caminho para afirmar-se como uma potência regional. O texto é concluído com a seguinte sentença:

É chegada a hora de o mundo parar de considerar o Brasil como parte daquilo que, na segunda metade do século XX, foi chamado de América Latina, um conceito que seguramente perdeu a utilidade que talvez tenha tido alguma vez. (BETHELL, 2009, p. 289)

O presente artigo toma como ponto de partida as proposições de Bethell, aliadas a questionamentos instigados por minha experiência profissional na UNILA (Universidade Federal da Integração Latino-Americana) em Foz do Iguaçu - universidade que, como o próprio nome anuncia, tem como referência a integração continental - para uma reflexão orientada a restituir a densidade política da noção de América Latina no século XXI, em particular para os brasileiros. Seu fio condutor é o nexo estabelecido entre as duas proposições conclusivas do artigo do historiador inglês: a impertinência em considerar o Brasil como parte da América Latina na atualidade, e como decorrência, a inutilidade do próprio conceito. Contrapondo-se a este raciocínio, procuro restituir as premissas históricas que conferem sentido à noção de América Latina como expressão de um desígnio de unidade continental, e como desdobramento, reafirmar os fundamentos políticos de um horizonte civilizatório para o Brasil referido à América Latina.

Para realizar este objetivo, o texto realiza o seguinte movimento: inicialmente, é reconstituído o contexto político e ideológico em que surge a expressão “América Latina”, com o objetivo de evidenciar as premissas que fundamentaram sua formulação original, como meio para apreciar sua atualidade. A seguir, procura-se delinear os marcos gerais que balizaram a evolução histórica de projetos identificados com o termo, até analisar as duas iniciativas de integração regional em curso que sustentam o argumento de Bethell, e não tem o subcontinente como referência. Finalmente, discutimos a atualidade política e ideológica da ideia de América Latina no Brasil. Nossa hipótese é que a pertinência desta noção está relacionada, por um lado, a uma apreciação da natureza dos nexos entre esta região e os Estados Unidos no mundo contemporâneo e, por outro, às premissas políticas que orientam o horizonte civilizatório que se projeta para o Brasil.

\section{GANPHLAC}

Revista Eletrônica da ANPHLAC, ISSN 1679-1061, №. 21, p. 261-297, Jul./Dez., 2016.

http://revista.anphlac.org.br 


\section{Atualidade da América Latina}

1.

Os dois estudos seminais em torno à gênese do termo América Latina foram publicados no ano de 1965, respectivamente pelo historiador estadunidense John Phelan e pelo filósofo uruguaio Arturo Ardao (PHELAN, 1986 (1965); ARDAO, 1965; 1980). Phelan argumenta que a noção de "América Latina" como uma entidade geopolítica foi cunhada e difundida nos marcos da ideologia panlatina forjada durante o império de Napoleão III na França. O historiador estadunidense sugere que o nexo ideológico entre a "Europa Latina", expressão de curso corrente no Velho Mundo naquela conjuntura, e a "América Latina" seria principalmente obra de um funcionário do império enviado ao Novo Mundo em decênios anteriores, Michel Chevalier. Nesta perspectiva, o termo indicaria uma área de potencial influência francesa na América, legitimando a invasão ao México iniciada em 1861 no contexto da Guerra da Secessão nos Estados Unidos, mesmo ano em que Chevalier publicou o artigo que Phelan considera como a referência original à expressão. A decorrência de maior impacto da hipótese do historiador estadunidense é uma leitura segundo a qual o termo "América Latina" teria sido forjado e difundido nos marcos da política expansionista francesa para o continente.

Quase simultaneamente ao trabalho de Phelan, Arturo Ardao apresentava resultados de uma pesquisa apontando em sentido diverso. O filósofo uruguaio mapeou múltiplas referências a uma "América Latina” em diversos políticos e publicistas da América hispânica em meados do século XIX, até identificar nos escritos do granadino José María Torres Caicedo nos anos 1850, e mais especificamente em um poema intitulado Las dos Américas, uma mudança significativa: o termo "latino" tornara-se um substantivo, e não mais um adjetivo de América. Desde então, a paternidade da expressão tem sido objeto de polêmica. O historiador chileno Miguel Rojas Mix defende a primazia de seu compatriota Francisco Bilbao, que teria veiculado o termo em uma conferência em Paris em 1856, cidade em que também vivia Torres Caicedo.

\section{GANPHLAC}

Revista Eletrônica da ANPHLAC, ISSN 1679-1061, №. 21, p. 261-297, Jul./Dez., 2016.

http://revista.anphlac.org.br 
Rojas sugere que o intelectual granadino apropriou-se do termo empregado por Bilbao, quem posteriormente o abandonaria por motivos políticos como resposta crítica à invasão francesa ao México (ROJAS MIX, 1986).

Mais recentemente, a historiadora estadunidense Aims McGuinness identificou a expressão em um texto intitulado La cuestión americana y su importancia, publicado no mesmo ano de 1856 pelo representante panamenho no Senado colombiano, Justo Arosemena. Reivindicado posteriormente como uma espécie de patrono do nacionalismo panamenho, Arosemena defendeu na ocasião um projeto de união hispano-americana em termos similares aos avançados por Torres Caicedo, ao mesmo tempo em que lutou pela autonomia desta província colombiana (MCGUINNESS, 2008, p. 99-101; AROSEMENA, 1982, p. 181-256).

O contexto que produziu esta circulação simultânea da expressão é iluminado pelo livro Path of Empire desta historiadora estadunidense. Estudando as relações entre a corrida para o oeste nos Estados Unidos e a questão social e racial na região do istmo do Panamá, a historiadora sugere nexos entre os conflitos decorrentes da expansão estadunidense e a difusão da expressão "América Latina". Em 1848, mesmo ano em que foi assinado o tratado Guadalupe-Hidalgo consumando a expansão territorial dos Estados Unidos a expensas do México vencido na guerra, anunciou-se a descoberta de ouro na Califórnia. Este episódio desencadeou migrações massivas de americanos do leste para o oeste do país, forçados a atravessar o continente por um de seus pontos mais estreitos: seja o istmo de Tehuantepec no México, a rota nicaraguense aproveitando-se do lago no interior do país, ou mais comumente, através do Panamá, que integrava a Nova Granada (futura Colômbia) naquele momento. Este afluxo em massa de estadunidenses à região causou diversos conflitos analisados por McGuinness, culminando, em 1856, na primeira de muitas intervenções militares estadunidenses na história panamenha.

Foi neste mesmo ano, após prestar serviços à facção vencedora na guerra civil entre as cidades de Leon e Granada, que ascendeu à presidência da Nicarágua o famoso filibusteiro William Walker. Múltiplas motivações se entrelaçaram na empreitada deste filho do Tennessee, incluindo a disputa entre empresários ianques pela exploração da rota interoceânica através do Lago Nicarágua e o projeto sulista de adicionar um voto escravista à federação,

\section{GANPHLAC}

Revista Eletrônica da ANPHLAC, ISSN 1679-1061, №. 21, p. 261-297, Jul./Dez., 2016.

http://revista.anphlac.org.br 
como pretendeu a fracassada expedição de Narciso Lopez a Cuba em 1850. De fato, em seu breve governo, reconhecido pelos Estados Unidos, Walker aboliu as leis antiescravistas. Deposto por uma coligação militar liderada pelo presidente da Costa Rica, o filibusteiro prosseguiu em suas atividades até ser executado por autoridades hondurenhas em 1860.

Antes de serem episódios isolados, estes eventos evidenciam o movimento de expansão estadunidense, embalado pela ideologia do Destino Manifesto em uma conjuntura em que os interesses do país também se expandiam em direção à Ásia (WILLIAMS, 1962). É este o substrato político da ocorrência simultânea da expressão em Torres Caicedo, Bilbao e Arosemena, quem, diga-se de passagem, cita a conquista do Texas, o filibusteiro William Walker e a expedição do Comodoro Perry ao Japão em sua defesa do "interés latinoamericano". Assim, a despeito da polêmica em torno do pioneirismo no emprego do termo, a senda aberta por Ardao mostra que, ainda que a matriz ideológica subjacente à expressão "América Latina" seja tributária da cultura europeia em geral e francesa em particular, foi como uma reação política nativa à projeção estadunidense, particularmente na América Central, que o termo ganhou a densidade histórica que o consagrou.

2.

Afastando-se da polêmica em torno à paternidade do termo, a historiadora argentina Monica Quijada critica a visão de Phelan adicionando um argumento político ao debate, ao perguntar-se porque adotariam os latino-americanos um termo identificado com uma agressão unanimemente condenada na região. Aceitando a gestação endógena da expressão, Quijada enfoca, portanto, um problema diverso: porque a expressão América Latina foi adotada nos anos seguintes, em detrimento de concorrentes como América Espanhola ou Gran Colombia (QUIJADA, 1998, p. 610)?

Segundo esta historiadora, a explicação decorre da confluência entre dois fatores: o ressurgimento de tendências que advogavam a unidade entre os países da América espanhola, em resposta ao expansionismo estadunidense, e a "racialização" das categorias explicativas, parte de um fenômeno geral no ocidente no século XIX. Assim, tanto Bilbao como Torres Caicedo (bem como Arosemena, que não é citado em seu texto), referem-se à oposição entre

\section{GANPHLAC}

Revista Eletrônica da ANPHLAC, ISSN 1679-1061, №. 21, p. 261-297, Jul./Dez., 2016.

http://revista.anphlac.org.br 
a América Latina e a América anglo-saxônica em termos raciais: "la raza latinoamericana", descreve o chileno no seu "Evangelho Americano", enquanto o poema do segundo diz "La raza de la América latina al frente tiene la sajona raza."

Neste sentido, embora gestada na América hispânica, a dicotomia entre América Latina e América Anglo-saxônica está referida a um vocabulário e a uma visão de mundo característicos da Europa do século XIX, em que era corrente a oposição entre a Europa Latina e a Anglo-saxônica, ou germânica, como lembra Quijada:

De hecho, al promediar el siglo XIX era tan normal hablar de las "razas" en general, de la división del género humano en "razas superiores" e "inferiores" e incluso de las rivalidades entre la "raza latina" y la "germana" o "anglosajona", como lo es hoy referirse a "culturas", a "naciones", o a las rivalidades entre Estados. (QUIJADA, 1998, p. 604)

Quais as vantagens subjetivas, do ponto de vista dos hispano-americanos, em adotar a denominação "América Latina"? Segundo a historiadora espanhola, a filiação latina conferia projeção universal aos seus dilemas, inscritos na oposição entre latinos e anglo-saxões, o que poderia motivar simpatia europeia a sua causa, mas, sobretudo, pode ser interpretado como uma maneira de afirmar o estatuto civilizatório daqueles que Benedict Anderson chamou como os "Estados Criollos" (ANDERSON, 2003). O intelectual chileno Walter Mignollo, que também se debruçou sobre o problema, acrescenta uma perspectiva de classe a este argumento quando aponta que a reivindicação latina não contradizia a reprodução dos privilégios sociais, assentada na discriminação de negros e indígenas no continente (MIGNOLLO, 2005).

A identidade latino-americana se afirmaria nos decênios seguintes à luz dos esforços do secretário de Estado norte-americano James Blaine para concretizar uma união panamericana, em nome da qual convocou uma conferência em Washington nos anos 1880 . No entanto, seria a intervenção dos Estados Unidos na guerra de independência de Cuba em 1898, que se converteu então em uma "Guerra Hispano-americana", o marco referente desta consciência hispano-americana, como mostra entre outros, o crítico literário espanhol Teodosio Fernández (FERNÁNDEZ, 2000). A indignação frente à agressividade dos Estados Unidos aproximaria homens de letra hispano-americanos das raízes espanholas do

\section{GANPHLAC}

Revista Eletrônica da ANPHLAC, ISSN 1679-1061, №. 21, p. 261-297, Jul./Dez., 2016.

http://revista.anphlac.org.br 
continente, a despeito da simpatia generalizada com a causa cubana prevalente na época. Assim, no próprio ano de 1898, Ruben Dario mobilizou a figura de Caliban em defesa do campo hispânico, e na virada do século, o uruguaio José Enrique Rodó celebrizará no continente a dicotomia com Ariel em seu ensaio. Entre outras expressões desta consciência identitária nos anos seguintes é possível mencionar, em polos opostos do subcontinente, a utopia da "Nação Latino-americana" avançada pelo argentino Manuel Ugarte, e as especulações em torno a uma "raça cósmica" do ministro revolucionário mexicano José Vasconcelos - indicando a longevidade da noção de raça na América Latina, ainda que em uma direção humanista, sugerida pela consigna que batizou a UNAM (Universidad Nacional Autonoma de México): "por mi raza hablará el espíritu"

Retomando o argumento de Monica Quijada, observa-se que no processo de afirmação da identidade latino-americana no final do século XIX e princípios do século XX, conflui uma reação ao expansionismo estadunidense com o que a historiadora espanhola denomina como uma "racialização" das categorias explicativas. Assim, a "América Latina" afirma-se em oposição à “América Anglo-saxônica” e por aproximação ao legado latino da cultura europeia. Depois dos eventos na América Central que motivaram o termo na sua origem, Quijada identifica na Primeira Conferência Pan-americana convocada por James Blaine e na Guerra da Independência Cubana entre 1895-98, dois marcos sucessivos neste processo identitário.

Houve um personagem que participou destes dois eventos e cujo ideário, na minha leitura, endossa a interpretação de Quijada por um caminho complementar. O cubano José Martí (1853-1898) participou da Conferência Pan-americana em 1889 como delegado pelo Uruguai e teve atuação decisiva juntamente com o delegado argentino, Roque Saenz Peña, para frustrar os desígnios estadunidenses. Saenz Peña, que depois seria presidente da Argentina, cunhou o lema "América para a humanidade" em oposição à doutrina Monroe, enquanto Martí pronunciou um de seus discursos mais famosos, "Madre América", em um evento cultural em que estavam presentes os delegados da Conferência.

Martí também foi o mentor intelectual e principal articulador do Partido Revolucionario Cubano, fundado poucos anos depois (1892), responsável por desencadear a Guerra da Independência em 1895. Exegetas do pensamento martiano, como Fernandez

\section{GANPHLAC}

Revista Eletrônica da ANPHLAC, ISSN 1679-1061, №. 21, p. 261-297, Jul./Dez., 2016.

http://revista.anphlac.org.br 
Retamar, localizam no final dos anos 1880 a maturação do ideário do militante cubano, que se condensaria no projeto de Nuestra América. Dois eventos são considerados determinantes para esta evolução: os protestos operários em Chicago no ano de 1886 (que estão na origem do $1^{\circ}$ de maio como dia do Trabalhador) e a referida Conferência Pan-americana. Deve-se lembrar que Martí vivia nos Estados Unidos, depois de circular por diversos países latinoamericanos (como México, Guatemala e Venezuela), já que estava banido de Cuba desde a sua prisão aos dezessete anos - pena que seu pai, um militar espanhol em serviço na ilha, conseguiu comutar pelo exílio.

Consciente da vulnerabilidade da posição cubana, premida entre o colonialismo espanhol e o expansionismo estadunidense, Martí inscreverá a guerra da independência nas Antilhas em uma problemática mais ampla: o destino da América Latina. Para realizar este movimento, o cubano realiza o seguinte percurso ideológico: em primeiro lugar, busca um denominador comum entre os países americanos ao sul do Rio Bravo, que localizará na história: Martí identifica uma origem comum, que por sua vez, projeta um potencial civilizatório conjunto, percepção sintetizada em uma linha de sua alocução Madre América: Del arado nació la América del Norte, y la Española, del perro de presa (Martí, 2000. p. 420-27, tomo 2).

Em segundo lugar, Martí valoriza a especificidade da cultura latino-americana, na qual identifica um potencial civilizatório único e original, ao mesmo tempo em que salienta o estatuto particular da cultura europeia. Como premissas desta reivindicação do americano, Martí integra o indígena e o negro ao seu projeto de formação nacional e continental, em contraste notável, por exemplo, com Justo Arosemena, cuja confederação americana discriminava negros e aborígenes. A democratização radical do seu projeto político encontra correspondência em um movimento no plano das ideias, em que o pensador cubano rechaça a noção de raça como categoria social válida: "El hombre no tiene ningún derecho especial porque pertenezca a una raza o otra: dígase hombre, y ya se dicen todos los derechos" (MARTÍ, 2000, p. 205).

Este humanismo radical que embasa a política martiana o leva a desmascarar o substrato ideológico da dicotomia civilização e barbárie, nas antípodas do pensamento de Sarmiento:

\section{GANPHLAC}

Revista Eletrônica da ANPHLAC, ISSN 1679-1061, №. 21, p. 261-297, Jul./Dez., 2016.

http://revista.anphlac.org.br 
[...] el pretexto de que la civilización, que es el nombre vulgar con que corre el estado actual del hombre europeo, tiene derecho natural de apoderarse de la tierra ajena perteneciente a la barbarie, que es le nombre que los que desean la tierra ajena dan al estado actual de todo hombre que no es de Europa o de la América europea". (MARTÍ, 2000, p. 450, tomo 1)

É pertinente recordar que Martí conheceu, quando esteve no Haiti, a Antenor Firmin, autor da obra De l'égalité des races humaines, uma resposta contundente proveniente da república negra das Antilhas ao ensaio de Gobineau sobre a desigualdade das raças humanas, de extraordinária repercussão na Europa (FIRMIN, 2005).

Em suma, ao projetar a luta cubana sobre o destino latino-americano, Martí buscou na história elementos de uma identidade comum cuja especificidade procura valorizar, o que o leva a rechaçar a racialização das categorias: é este humanismo radical que substancia a aliança social que sustenta a política do PRC, sintetizada na consigna: "con todos y para el bien de todos"

Por outro lado, Martí afasta-se de uma identificação do destino continental com a cultura latina e projeta um horizonte civilizatório próprio, alicerçado na autoctonia. Nas suas palavras, "La universalidad europeia ha de ceder a la universalidad americana". Daí a valorização dos povos aborígenes, traduzida na afirmação de que a nossa Grécia é preferível à Grécia que não é nossa, por nos ser mais necessária, assim como o vinho de plátano: “Injértese en nuestras repúblicas el mundo; pero el tronco ha de ser el de nuestras repúblicas”, sentencia Martí (MARTÍ, 2000, p. 483, tomo 2).

O ideário humanista martiano é sintetizado na noção de "hombre natural", que supõe uma natureza humana transcendente para o homem americano, em contraste com o materialismo que domina a sociedade europeia e estadunidense. Martí propõe para o continente uma sociabilidade alternativa, alicerçada em uma racionalidade amorosa de inspiração cristã em oposição ao "ódio de classes" prevalente nas sociedades industriais.

Premido entre o colonialismo espanhol e o expansionismo estadunidense, Martí projeta para o continente um horizonte civilizatório alternativo, que não está referido à Europa latina nem aos Estados Unidos. Em face a este dilema, é levado a buscar uma denominação que

\section{GANPHLAC}

Revista Eletrônica da ANPHLAC, ISSN 1679-1061, №. 21, p. 261-297, Jul./Dez., 2016.

http://revista.anphlac.org.br 
reflete de maneira lapidar os paradoxos envolvidos: nuestra América, termo empregado anteriormente por diversos americanos, mas cujo sentido político original é geralmente atribuído a Francisco de Miranda (BOHÓRQUEZ MORÁN, 2003, p. 20). Ao adotar este termo, Martí assume a denominação europeia para a região, apropriada pelos Estados Unidos (“América”), indicando ao mesmo tempo que o subcontinente está destinado a não ser latino nem americano - no sentido inferido pela Doutrina Monroe. Afirma que seremos América afinal - como vislumbraram os europeus e projetaram os estadunidenses - mas do nosso jeito.

Assim, convergem no ideário de nuestra América um projeto geopolítico defensivo face ao expansionismo estadunidense e uma utopia humanista própria e original, de alcance universal. É neste duplo sentido que o pensador cubano identificou o desenlace da guerra nas Antilhas com o "equilíbrio del mundo":

\footnotetext{
La guerra de independencia de Cuba, nudo del haz de islas donde se ha de cruzar, en plazo de pocos años, el comercio de los continentes, es suceso de gran alcance humano, y servicio oportuno que el heroísmo juicioso de las Antillas presta a la firmeza y trato justo de las naciones americanas, y al equilibrio aún vacilante del mundo. (MARTÍ, 2000b, p. 517)
}

Retomando o diálogo entre a hipótese de Quijada e a análise de Martí, verificamos que, impossibilitado de identificar o destino latino-americano com a Europa latina em uma circunstância em que a Espanha era o inimigo imediato, o pensador cubano descarta a racialização das categorias ao mesmo tempo em que refere à autoctonia o horizonte civilizatório de sua utopia de unidade continental face ao expansionismo estadunidense. Antes de ser uma operação ideológica, este movimento corresponde a uma radicalização política de sentido democrático do projeto martiano, que permite situá-lo entre os esforços pioneiros para subordinar o desenvolvimento capitalista aos desígnios da sociedade nacional no contexto de difusão das relações de produção capitalistas no continente.

Nesta perspectiva, o desenlace da Guerra da Independência cubana, em que a intervenção militar estadunidense no ocaso do conflito frustra a emancipação nacional, encerra um paradoxo. Por um lado, conforme já observado, a imediata derrota espanhola no confronto com os Estados Unidos no Caribe e na Ásia provocou uma onda de hostilidade à potência

\section{GANPHLAC}

Revista Eletrônica da ANPHLAC, ISSN 1679-1061, №. 21, p. 261-297, Jul./Dez., 2016.

http://revista.anphlac.org.br 
americana, que se desdobrou em uma reivindicação da latinidade, evidenciada na repercussão do ideário arielista esboçado por Rodó. Por outro lado, na crítica arielista à "nordomania", ressoa a racialização das categorias referida por Quijada. A radicalidade democrática do projeto martiano derrotado, em que índios e negros eram protagonistas, é dissolvida em uma ideologia compatível com a reprodução dos privilégios sociais que caracterizavam as repúblicas criollas coevas.

Para nomear o problema em vocabulário político contemporâneo, a reação prevalente aos acontecimentos de 1898 na América Latina evidenciou a dimensão nacional do antiimperialismo a expensas do seu conteúdo de classe, prefigurando um dilema recorrente na política democrática do continente ao longo do século $\mathrm{XX}^{2}$.É este descolamento entre soberania e igualdade que o intelectual cubano Fernández Retamar endereçou quando, no contexto da revolução cubana, reivindicou o papel de Caliban em lugar de Ariel para a América Latina, invertendo a leitura de Rodó.

3.

Até este ponto, indicamos que a noção de América Latina se afirma em resposta a expansão estadunidense, em um contexto em que a racialização das categorias informa um projeto político de unidade do subcontinente. Na sequência, ao recuperar o ideário martiano, observamos que a superação das categorias raciais corresponde a uma radicalização da dimensão democrática da integração nacional, que se articula à reivindicação de uma originalidade histórica como ponto de apoio de um projeto de unidade continental, vislumbrado simultaneamente como uma estratégia geopolítica defensiva face aos Estados Unidos e um horizonte civilizatório próprio de estatura universal.

Neste ponto, é possível localizar com precisão as premissas políticas que fundamentam a vitalidade do conceito de América Latina no século XXI: a pertinência de uma política de integração continental para contrariar as pressões do capital internacional em geral e dos

\footnotetext{
${ }^{2}$ Para dar dois exemplos: o debate entre Mariátegui e Victor Raul Haya de la Torre, líder do APRA; e os impasses na relação entre operários e movimento indígena na história da Bolívia, em particular na revolução de 1952 - que por sua vez, remetem ao problema da aliança operário-camponesa.
}

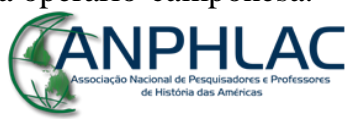

Revista Eletrônica da ANPHLAC, ISSN 1679-1061, №. 21, p. 261-297, Jul./Dez., 2016.

http://revista.anphlac.org.br 
Estados Unidos em particular, nos marcos de uma estratégia para assumir o controle sobre o tempo e o ritmo da mudança social, objetivando afirmar sociedades relativamente equitativas e autorreferidas. Ou, para enunciar em uma linha, sua pertinência está referida a uma apreciação da atualidade de um projeto de unidade continental no contexto do imperialismo.

\section{Historicidade da unidade continental}

Tomando como referência as considerações acima sobre o conteúdo político do conceito de América Latina, abordarei a seguir uma segunda proposição, de Bethell, sugerindo a impertinência de enquadrar o Brasil como parte da América Latina no século XXI. Desenvolverei meu argumento em dois movimentos articulados, assentados em premissas enunciadas nos parágrafos anteriores. Por um lado, recupero sucintamente a historicidade dos projetos de unidade continental, lembrando que seu conteúdo evolui em consonância com o próprio movimento da história latino-americana. Por outro lado, sugiro que a constatação de que os brasileiros raramente se enxergam ou se enxergaram como parte da América Latina não deve servir como premissa para um argumento de viés tautológico, justificando o que se pretende explicar. Ao contrário, este distanciamento deve ser problematizado à luz da dinâmica da luta de classes no país, endereçando, em última análise, a seguinte questão: a quais brasileiros interessa construir-se como parte da América Latina?

1.

Ao longo da história independente da América Latina, o desígnio de unidade continental se revela indissociável da problemática da formação nacional, entendida como a superação do legado colonial substanciada na articulação entre dependência externa e assimetria social, visando consolidar as bases materiais, sociais, espaciais, políticas e culturais do Estado nacional. Em outras palavras, a unidade continental foi, desde Bolívar, projetada como uma estratégia defensiva, objetivando assegurar a soberania das jovens nações em um contexto internacional assimétrico e predatório. No entanto, este desígnio sempre padeceu de um

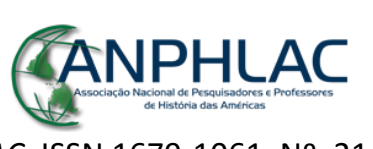

Revista Eletrônica da ANPHLAC, ISSN 1679-1061, №. 21, p. 261-297, Jul./Dez., 2016.

http://revista.anphlac.org.br 
paradoxo, na medida em que a almejada capacidade de guiar o próprio destino, a ser fortalecida pela união regional, revela-se como requisito necessário para consumar a unidade pretendida. O intelectual e militante peruano José Carlos Mariátegui assinalou com precisão o dilema em meados dos anos 1920:

Pero lo que separa y aisla a los países hispano-americanos, no es esta diversidad de horario político. Es la imposibilidad de que entre naciones incompletamente formadas, entre naciones apenas bosquejadas en su mayoría, se concerte y articule un sistema o un conglomerado internacional. En la historia, la comuna precede a la nación. La nación precede a toda sociedad de naciones. (MARIÁTEGUI, 1990, p. 14)

Nesta perspectiva, o significado e o conteúdo político de um projeto de unidade latinoamericana orientado à soberania evoluíram desde a independência, de maneira correspondente ao próprio dilema da formação nacional. Partindo de uma situação na qual colônia e metrópole conformam uma unidade, a trajetória dos países americanos pode ser lida como uma progressiva diferenciação em direção à nação, a qual corresponde uma percepção do continente como uma totalidade histórica. Em linhas gerais, um olhar retrospectivo sugere uma progressiva evidenciação das dimensões política, cultural, social e econômica que compõem a especificidade continental ${ }^{3}$.

Ponto de ruptura da unidade colônia-metrópole que caracterizava o antigo sistema colonial, as guerras de independência colocaram a questão da soberania como um problema político, que envolve uma dimensão cultural quando Bolívar defende instituições adequadas à realidade local. Neste contexto, a unidade continental é projetada como um meio para assegurar a independência conquistada pelas armas e ameaçada pela reação europeia no contexto da Santa Aliança.

A necessidade de consumar a unidade nacional evidencia uma dimensão cultural da especificidade continental ao longo do século XIX, na medida em que a construção das nacionalidades enseja a afirmação de referências culturais e históricas próprias, convergentes com o processo de consolidação do Estado nacional. A dimensão continental desta problemática

\footnotetext{
${ }^{3}$ A respeito da progressiva diferenciação das esferas política, cultural, social e econômica através de um processo histórico que evidenciou a especificidade da formação latino-americana, consultar: FERNÁNDEZ, 2005; PINEDO, 2010; ZEA, 1995.
}

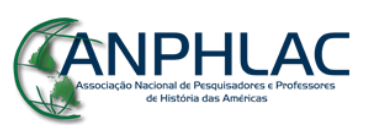

Revista Eletrônica da ANPHLAC, ISSN 1679-1061, №. 21, p. 261-297, Jul./Dez., 2016.

http://revista.anphlac.org.br 
encontra expressão pioneira na trajetória e obra dos caraquenhos Andres Bello (1781-1865) e Simón Rodríguez (1769-1854), quem escreveu: "Donde iremos a buscar modelos?...- La América Española es original - ORIGINALES han de ser sus Instituciones y su Gobierno = ORIGINALES los medios de fundar uno y otro. O Inventamos o Erramos" (RODRÍGUEZ, 1990, p. 88, grifos no original).

Por outro lado, nas regiões em que se evidencia a fragilidade da soberania alcançada frente ao expansionismo estadunidense a partir de meados do século XIX ressurgem propostas de unidade continental, conforme vimos, informadas pelo vocabulário racial em voga na Europa. Novamente, o risco que se pretende prevenir é principalmente a intervenção militar, embora a ameaça primordial não seja mais a Europa, onde a Santa Aliança se esfacelou no contexto revolucionário de 1848, mas os Estados Unidos.

No final do século XIX, em um contexto de afirmação do capital monopolista e difusão das relações de produção capitalistas, observa-se a passagem entre uma percepção política e cultural da especificidade continental e a apreensão dos dinamismos sociais e econômicos que conformam uma realidade própria na qual a aspiração por soberania e integração nacional opõese ao movimento do imperialismo. Nesta conjuntura, afloram projetos de democratização radical das sociedades americanas em que a natureza singular desta formação histórica impõe aos militantes o desafio de discernir entre os aspectos comuns e as particularidades do desenvolvimento nacional em relação ao padrão civilizatório dos países centrais, em uma circunstância na qual fatores objetivos e subjetivos obstam esta diferenciação. Esta problemática se evidencia no contraste entre o modo como a América Latina e sua população nativa é abordada por três expoentes da política radical latino-americana na virada do século (XIX-XX): José Martí (1853-1895) em Cuba, Juan B. Justo (1865-1928) na Argentina e Ricardo Flores Magón (1874-1922) no México.

Tributário da tradição sarmentina do pensamento argentino, o socialista Juan B. Justo identifica o aborígene com a barbárie, pregando uma adesão irrestrita aos valores da civilização ocidental. No extremo oposto do subcontinente, Ricardo Flores Magón reivindica o potencial comunista das populações originárias quando os trabalhadores rurais protagonizam a Revolução Mexicana (1910-1920), enquanto a chave da política revolucionária martiana é a

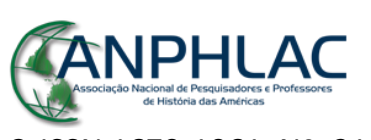

Revista Eletrônica da ANPHLAC, ISSN 1679-1061, №. 21, p. 261-297, Jul./Dez., 2016.

http://revista.anphlac.org.br 
autoctonia, que se expressa em uma valorização do potencial civilizatório singular de Nuestra América.

A despeito de numerosas especificidades dos respectivos contextos, a postura contrastante de Justo está lastreada na falta de uma percepção crítica do imperialismo, preocupação fundamental na política dos líderes cubano e mexicano. Longe de excepcional, a leitura política do socialista portenho, que pretendia engatar o vagão argentino na locomotiva civilizatória ocidental, está referida à "ilusão do progresso" que envolvia o debate político nacional, em um contexto em que o país saltara em poucas décadas da condição de deserto demográfico polvilhado de gauchos e índios, para a sexta economia mundial. A força desta ideologia é ilustrada pela baixa incidência política que teve a pregação de Manuel Ugarte, pioneiro na denúncia de um imperialismo estadunidense na Argentina, defensor da unidade latino-americana e da autodeterminação econômica do país (UGARTE, 1987; GALASSO, 2001; ANEGEL BARRIOS, 2007).

No polo geográfico oposto do continente, entretanto, era impossível ignorar os desdobramentos geopolíticos do processo de centralização de capitais, que se expressava no expansionismo estadunidense (LAFEBER, 1969, p. 102). Para Ricardo Flores Magón, assim como para todos os protagonistas da política mexicana até a Revolução (1910-1920), era necessário incluir em seu cálculo político o risco sempre presente de uma intervenção militar estadunidense. De modo análogo, para José Martí a ameaça ianque assumia a feição concreta de uma invasão militar, que afinal se consumou. Devemos lembrar, a propósito, que as tropas dos Estados Unidos operaram numerosas intervenções na América Central e no Caribe desde o século XIX e que, embora concentradas nos primeiros decênios do século XX, incluem invasões recentes ao Panamá (1989) e ao Haiti.

O ponto a enfatizar é que, embora os riscos da dependência econômica não fossem inteiramente alheios a Flores Magón nem a Martí, o ângulo pelo qual encaram a unidade regional é primordialmente militar, conforme enunciado no programa do Partido Liberal Mexicano de 1905, liderado por Flores Magón:

En el establecimiento de firmes lazos de unión entre los países latinoamericanos, podrán encontrar esos países - entre ellos México - una garantía para la conservación

\section{GANPHLAC}

Revista Eletrônica da ANPHLAC, ISSN 1679-1061, №. 21, p. 261-297, Jul./Dez., 2016.

http://revista.anphlac.org.br 
de su integridad, haciéndose respetables por la fuerza de su unión ante otros poderes que pretendieran abusar de la debilidad de alguna nación latinoamericana. (PLAN DEL PARTIDO LIBERAL, 1974, p. 111)

Em suma, em um contexto em que o incipiente desenvolvimento das relações de produção capitalistas inibia a diferenciação da esfera econômica, a apreensão dos nexos entre as esferas da existência e sua relação com o capital internacional mostrava-se limitada. Neste contexto, propostas que apontam para uma unidade regional encontram maior ressonância em situações nas quais a integridade territorial e a soberania política encontram-se ameaçadas pelos Estados Unidos. Por outro lado, afloram projetos de democratização radical das sociedades americanas, em que a emergência da questão social problematiza o lugar dos não latinos nas "repúblicas criollas", evidenciando mais uma dimensão da especificidade continental em um movimento que será aprofundado nos decênios seguintes em torno da questão indígena, principalmente no México e em países andinos.

\section{2.}

A possibilidade de análise política do econômico, permitindo articular os problemas nacionais e continentais ao movimento do capital internacional como uma totalidade, consolidar-se-á com a difusão de um padrão capitalista de estratificação social, impulsionado em particular pelo processo de industrialização substitutiva de importações. É nos marcos desta evolução que a autodeterminação econômica será percebida como uma dimensão fundamental do problema da formação da nação, questão que ganhará evidência política a partir dos efeitos da crise de 1929 no continente. José Aricó anota esta inflexão para o caso argentino, em relação à conjuntura em que militou Juan B. Justo no começo do século XX:

En tal sentido, vale la pena recordar que salvo en las fantasmagóricas recreaciones de estas corrientes "nacionales", no existió en la Argentina anterior a los años treinta ningún grupo que opusiera un programa de desarrollo económico alternativo, y fundado en el predominio industrial, al impuesto por el bloque oligárquicoimperialista. (ARICÓ, 1999, p. 107)

\section{CANPHLAC}

Revista Eletrônica da ANPHLAC, ISSN 1679-1061, №. 21, p. 261-297, Jul./Dez., 2016.

http://revista.anphlac.org.br 
Esta evolução política está lastreada em uma diferenciação da esfera econômica ${ }^{4}$ que tem como principal expressão ideológica a constituição de uma corrente de economia política latino-americana que se consolida em torno de Raúl Prebisch a partir da fundação da CEPAL em 1947. No entanto, como mostra Eduardo Devés Valdés, este movimento articula elementos da ciência econômica contemporânea a um conjunto de motivos presentes no pensamento latino-americano ao menos desde os anos 1920, e não deve ser entendido como uma geração espontânea nem como aplicação reflexa de teorias europeias (DEVÉS VALDÉS, 2000, p. 292).

Nesta perspectiva, é notável que no período entreguerras o ideário de unidade continental associou-se à dimensão classista do problema da soberania, que inclui a esfera econômica em um contexto de generalização de uma percepção anti-imperialista associada ao nacionalismo. Ainda nos anos 1910, o desenlace da Primeira Guerra Mundial favoreceu uma crítica à Europa como paradigma civilizatório, ao mesmo tempo em que o triunfo bolchevique impulsionou a difusão do comunismo e do materialismo histórico na América Latina, em um momento em que o impacto da Revolução Mexicana encorajava horizontes políticos radicais. Assim, o primeiro manifesto do processo de reforma universitária que eclodiu na cidade argentina de Córdoba em 1918, e logo se espalhou por toda a América Latina, anunciava a chegada de uma "hora americana" (LA JUVENTUD ARGENTINA, 1978, p. 131). Entre os múltiplos desdobramentos do movimento, fundou-se uma organização com o propósito de reunir os intelectuais anti-imperialistas do continente, a Unión Latinoamericana, capitaneada pelo controverso José Ingenieros.

De maior impacto político foi a constituição do APRA (Alianza Popular Revolucionaria Americana) em 1924, ainda sob a efervescência da Revolução Mexicana, sob a liderança do estudante peruano Victor Raul Haya de la Torre. Organização referente da política peruana no século XX, o partido foi originalmente projetado no México como uma organização continental. No final dos anos 1920, Haya de la Torre protagonizou com Mariátegui e o estudante cubano Julio Antonio Mella, que também aderiu ao marxismo, uma polêmica em torno da conveniência de uma estratégia de aliança anti-imperialista com setores da burguesia, quando seus

\footnotetext{
${ }^{4}$ Sobre o processo histórico que está na raiz do surgimento da economia política como ciência autônoma na Europa contemporânea à Revolução Industrial, consultar: POLANYI, 2001.
}

\section{CANPHLAC}

Revista Eletrônica da ANPHLAC, ISSN 1679-1061, №. 21, p. 261-297, Jul./Dez., 2016.

http://revista.anphlac.org.br 
interlocutores comunistas questionavam, de modo pioneiro, a existência de uma burguesia nacional no continente.

No entanto, a difusão de um sentimento anti-imperialista no continente, que se expressou em um apoio generalizado à resistência comandada por Sandino à ocupação estadunidense na Nicarágua no final dos anos 1920, não se traduziu, de imediato, em esforços por abordar o fenômeno a partir da economia. Embora atentasse para a importância da dimensão econômica da política, a questão fundamental dos artigos e das polêmicas em que se envolveu Mariátegui durante sua curta vida (1895-1930) foi as classes sociais, focalizando em particular a questão indígena e o seu país, o Peru. A despeito da extravagância teórica que caracterizaram as proposições de seu compatriota Victor Raul Haya de la Torre, apontadas por Michael Löwy como exemplo paradigmático da tentação do "excepcionalismo indo-americano" 5 - ou seja, uma tendência a absolutizar a singularidade da formação continental que ameaçou o marxismo no continente no século XX (LÖWY, 2003, p. 10) -, ambos os autores expressam um esforço em discernir e articular o específico e o comum na formação latino-americana no contexto do capitalismo monopolista. Embora escrita em 1928, a análise do líder do APRA sobre o imperialismo, El antimperialismo y el APRA, foi publicada somente em 1935 e sua notável difusão indica um contexto em que esta problemática se populariza no continente, como anotou Devés Valdés:

El antiimperialismo es uno de los temas recurrentes del pensamiento latinoamericano de los años 30 y puede incluso señalarse que es la forma que asume el pensamiento identitario de esos años, que se realiza como defensa de la economía continental o como nacionalismo económico. (DEVÉS VALDÉS, 1999, p. 204)

3.

O avanço da industrialização substitutiva de importações, decorrente dos efeitos da depressão econômica do entreguerras na América Latina, gerou o contexto em que se afirmou a possibilidade de teorizar o continente como uma totalidade a partir da esfera econômica,

\footnotetext{
5 "O excepcionalismo indo-americano tende a absolutizar a especificidade da América Latina e de sua cultura, história ou estrutura social. Levado às suas últimas consequências, esse particularismo americano acaba por colocar em questão o próprio marxismo como teoria exclusivamente européia" (LOWY, 2003, p. 10).
}

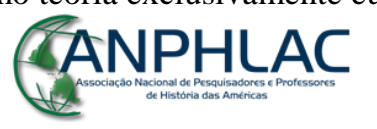

Revista Eletrônica da ANPHLAC, ISSN 1679-1061, №. 21, p. 261-297, Jul./Dez., 2016.

http://revista.anphlac.org.br 
movimento que encontrou sua expressão mais destacada na corrente de pensamento econômico que se difundiu a partir da CEPAL. Embora seja difícil precisar cronologicamente esta inflexão, é possível constatar que, após a Segunda Guerra Mundial, a dimensão econômica da problemática da dependência será nuclear para os projetos políticos balizados pelo dilema da formação nacional, assim como para as propostas de integração regional, em contraste com o lugar marginal desta questão nos esforços em teorizar a formação latino-americana no começo do século XX.

O desenvolvimento econômico, identificado com a industrialização, passou a ser percebido como uma condição necessária, embora insuficiente, para afirmar a nação. Em suas formulações críticas mais penetrantes, o enfrentamento da dimensão econômica da dependência denunciada de modo pioneiro por Prebisch a partir da crítica à teoria das vantagens comparativas e ao desenvolvimento "hacia afuera", foi identificada como premissa para superar a articulação entre dependência externa e o padrão de privilegiamento social característicos do subdesenvolvimento, cuja raiz histórica na América Latina remonta às estruturas da colonização.

O subdesenvolvimento tem suas raízes numa conexão precisa, surgida em certas condições históricas, entre o processo interno de exploração e o processo externo de dependência. Quanto mais intenso o influxo de novos padrões de consumo, mais concentrada terá que ser a renda. Portanto, se aumenta a dependência externa, também terá que aumentar a taxa interna de exploração. Mais ainda: a elevação da taxa de crescimento tende a acarretar agravação tanto da dependência externa como da exploração interna. Assim, as taxas mais altas de crescimento, longe de reduzir o subdesenvolvimento, tendem a agravá-lo, no sentido de que tendem a aumentar as desigualdades sociais (FURTADO, 1974, p. 94).

A partir dos anos 1960, a evidenciação dos limites da industrialização substitutiva de importações como estratégia para enfrentar o subdesenvolvimento ensejou respostas teóricas de sentido diverso. As reflexões referidas ao pensamento cepalino enfatizaram a necessidade de avançar na integração econômica regional, para além do Mercado Comum CentroAmericano e da Associação Latino-Americana de Livre Comércio (ALALC) então existentes (NOLFF, 1975, p. 381). Concomitantemente, difundiram-se reflexões fora deste marco teórico

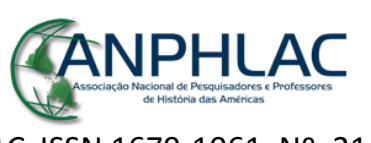

Revista Eletrônica da ANPHLAC, ISSN 1679-1061, №. 21, p. 261-297, Jul./Dez., 2016.

http://revista.anphlac.org.br 
que associava desenvolvimento a integração nacional, marco consagrado pela CEPAL desde Raúl Prebisch. A obra Dependência e desenvolvimento na América Latina, de Enzo Faletto e Fernando Henrique Cardoso, é paradigmática desta inflexão ideológica que atingiria a própria CEPAL nos anos seguintes, quando a hegemonia neoliberal consumaria a dissociação entre crescimento econômico e nação na América Latina (CARDOSO; FALETTO: 1977).

Por outro lado, o triunfo da revolução cubana em 1959 teve um impacto político e ideológico extraordinário no continente. Premido pela intransigente agressividade dos Estados Unidos, a rápida radicalização do processo explicitou a unidade entre os conteúdos nacional e democrático da revolução, problematizando a viabilidade histórica de afirmar a nação na América Latina nos marcos do capitalismo. Na esfera política, a hostilidade permanente sofrida pelo processo cubano no âmbito da OEA (Organização dos Estados Americanos) evidenciou a conduta servil dos estados latino-americanos diante dos Estados Unidos, expressão da unidade de interesses que aproximava as classes dominantes à potência hegemônica na região.

$\mathrm{O}$ acirramento da luta de classes nesta conjuntura se materializou no afloramento ou revigoramento de movimentos guerrilheiros em todo o continente, e que o estado cubano procurou incentivar por meio da OLAS (Organização Latino-Americana de Solidariedade), ao mesmo tempo em que ditaduras militares assumiram o comando da repressão política e social em diversos países, com apoio explícito dos Estados Unidos. Esta regionalização da luta de classes contribuiu para projetar o dilema da formação nacional em um horizonte continental, em um contexto em que a solidariedade entre os repressores, cujas expressões paradigmáticas foram a Escola das Américas e a Operação Condor, correspondia à intensificação da presença de multinacionais de capital estadunidense na região, acirrando os impasses vivenciados pelo processo de substituição de importações.

A solidariedade entre os que resistiam à repressão, na luta armada ou no exílio, estimulou análises de escopo continental que, em resposta à radicalização da conjuntura, sugeriam a unidade do conteúdo democrático e socialista da revolução latino-americana. A corrente mais radical da teoria da dependência, expressa neste momento em autores como Ruy Mauro Marini, Teotonio dos Santos, Vania Bambirra, André Gunder Frank, Aníbal Quijano e Luis Vitale, assim como as análises de Florestan Fernandes, os documentos de numerosos

\section{GANPHLAC}

Revista Eletrônica da ANPHLAC, ISSN 1679-1061, №. 21, p. 261-297, Jul./Dez., 2016.

http://revista.anphlac.org.br 
partidos e organizações revolucionárias da época, além da militância paradigmática de Che Guevara, apontam para esta convergência entre nação, socialismo e unidade continental. No plano do Estado, alinhando-se sem ambiguidades à revolução cubana, o programa da Unidad Popular no Chile vinculou nacionalismo e anti-imperialismo à necessidade de refundar os marcos institucionais em que se articulavam os países latino-americanos:

\begin{abstract}
A posição de defesa ativa da independência do Chile implica na denúncia da atual OEA como instrumento e organização do imperialismo norte-americano e na luta contra qualquer forma de pan-americanismo implícita nessa organização. O Governo Popular providenciará a criação de um organismo realmente representativo dos países latino-americanos. (PROGRAMA, 1970, p. 111)
\end{abstract}

Processo político que sintetizou as esperanças de uma geração, a derrocada do governo da Unidad Popular comandado por Salvador Allende no Chile (1970-1973) assinalou em seu momento a derrota de um horizonte civilizatório, que apontava para a convergência entre nação e socialismo, referida a uma aproximação entre os povos do continente.

4.

Projetos de integração regional voltaram ao debate político continental nos anos 1990 no contexto da formação de blocos econômicos nos marcos da concorrência intracapitalista após o colapso soviético. Nesta perspectiva, a derrota dos projetos democrático-nacionais na América Latina no curso da Guerra Fria pode ser interpretada como um capítulo da derrota política que facultou a escalada neoliberal no mundo, evidente de modo paradigmático no desenlace da experiência da Unidad Popular no Chile (KLEIN, 2008, p. 76).

Em um movimento que se confunde com a própria globalização, a aceleração das tendências à financeirização do capitalismo pressionou por uma abertura econômica multilateral, associada à difusão da agenda política identificada com o neoliberalismo, em um processo cuja racionalidade reforçou a liderança geopolítica dos Estados Unidos (BRENNER, 2003; GOWAN, 2003). Expressão regional deste movimento, a constituição do NAFTA (North American Free Trade Agreement) e da UNASUL (União Sul-americana de Nações), iniciativas

\title{
GANPHLAC
}

Revista Eletrônica da ANPHLAC, ISSN 1679-1061, №. 21, p. 261-297, Jul./Dez., 2016.

http://revista.anphlac.org.br 
a que se refere Bethell, está referida a este contexto adverso às forças populares, cujas linhas gerais é preciso reconstituir.

Em 1990, no momento em que se desmanchava a União Soviética, o presidente George Bush lançou a "Iniciativa para as Américas", uma proposta de integração regional balizada pelo tripé livre comércio, fluxo de investimentos e pagamento da dívida externa, prevendo uma integração comercial hemisférica, excluindo Cuba. Em 1994, na 1ª Cúpula das Américas em Miami, a proposta ganhou corpo, substanciando-se no projeto da ALCA (Área de LivreComércio das Américas), que deveria ser implementada até 2005. Simultaneamente, entrou em vigor um acordo de livre comércio entre Estados Unidos, México e Canadá em 1994, o NAFTA. Entretanto, a proposta da ALCA enfrentou resistências do estado e de amplos setores da sociedade no Brasil e em outros países latino-americanos, resultando no fracasso da iniciativa, consumado na V Cúpula das Américas em 2005. A partir de então, os Estados Unidos adotaram como estratégia a assinatura de tratados bilaterais de livre-comércio, firmando acordos com países centro-americanos, Chile, Colômbia e mais recentemente, o Peru, ao mesmo tempo em que aprofundaram as dimensões que lhe interessavam na integração regional, principalmente relacionadas à segurança, por meio de iniciativas como a ASPAN (Aliança para a Segurança da América do Norte). Se o NAFTA e seus desdobramentos são identificados com uma integração subordinada, unanimemente condenada pelo campo popular no continente (ARROYO PICARD, 2009), o processo que levou a constituição da UNASUL está marcado por ambiguidades que devem ser ponderadas.

Ao se consumar o atrelamento da política mexicana aos Estados Unidos em meados dos anos 1990, a diplomacia brasileira visualizou progressivamente a América do Sul como referência geográfica de um projeto de liderança regional. Esta perspectiva materializou-se em uma aproximação entre o Mercosul e a CAN (Comunidade Andina das Nações), como uma estratégia para a constituição de um bloco econômico alternativo no espaço sul-americano. Foi neste contexto que surgiu, durante o governo de Fernando Henrique Cardoso, a proposta da IIRSA (Iniciativa para a Integração da Infraestrutura Regional Sul-americana), sinalizando para uma integração sul-americana referenciada no que a CEPAL descreveu neste momento como

\section{CANPHLAC}

Revista Eletrônica da ANPHLAC, ISSN 1679-1061, №. 21, p. 261-297, Jul./Dez., 2016.

http://revista.anphlac.org.br 
um "regionalismo aberto" - uma modalidade de integração regional orientada à abertura comercial multilateral ${ }^{6}$.

Originalmente pensada como a dimensão de infraestrutura deste projeto de integração regional, proposta em uma cúpula de presidentes sul-americanos em Brasília em 2000, a IIRSA foi repaginada pelo governo Lula, que a converteu no esteio material da UNASUL, constituída em 2008. Para justificar este movimento, os defensores da gestão petista alegam uma inflexão na orientação da política externa brasileira que teria abandonado o regionalismo aberto característico dos anos anteriores em nome de uma política que enfatiza a integração sulamericana como estratégia de inserção internacional soberana, descrita como "regionalismo desenvolvimentista" ou "pós-liberal". Nesta perspectiva, sugere-se que esta modalidade de integração promoverá

a integração física entre os interiores dos países, passo fundamental para a integração de cadeias produtivas de fornecedores e produtores relacionados, objetivando a formação de economias de escala e a própria integração das sociedades sulamericanas. (DESIDERÁ NETO, 2012, p. 32-33)

No entanto, esta proposição tem sido problematizada por múltiplas evidências políticas que incluem os paradoxos vivenciados pela diplomacia brasileira na crise que culminou na deposição do presidente Fernando Lugo no Paraguai em 2012, além dos numerosos conflitos socioambientais envolvendo a expansão das empreiteiras brasileiras no continente, apoiada na atuação controversa do BNDES, o que levou um analista a descrever a IIRSA como uma espécie de "PAC para a América do Sul” (NOVOA GARZÓN, 2011, p. 1). No plano teórico, ressurgem reflexões que resgatam, de modo explícito ou não, as proposições de Rui Mauro Marini nos anos 1970, apontando para o que este autor descreveu como um "subimperialismo brasileiro" (MARINI, 2000, p. 109).

A despeito de eventuais contradições políticas e inconsistências teóricas, o sentido geral destas contestações sugere que, sob o verniz de um "player" na disputa por um mundo

\footnotetext{
${ }^{6}$ A IIRSA prevê um conjunto de projetos de integração da infraestrutura regional nas áreas da comunicação, energia e transporte. Em seu relatório de 10 anos constavam 524 projetos com investimento estimado em 96 bilhões de dólares distribuídos em 47 grupos pertencentes a 9 Eixos de Integração e Desenvolvimento (IIRSA, 2011). Uma boa síntese das críticas originais à iniciativa é BARTESAGHI; CERONI; DÍAZ, 2006.
}

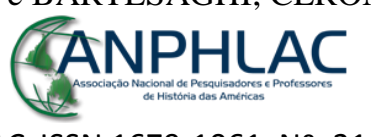

Revista Eletrônica da ANPHLAC, ISSN 1679-1061, №. 21, p. 261-297, Jul./Dez., 2016.

http://revista.anphlac.org.br 
multipolar, revela-se um estado a serviço da expansão de determinados setores capitalistas nacionais na América do Sul (como as empreiteiras e o agronegócio), por meio de uma modalidade de integração voltada à constituição de corredores de exportação de commodities, tais como a soja, o etanol e minérios e que aponta, em última análise, para uma reprimarização da economia do subcontinente sob a liderança regional brasileira, funcional ao movimento do capitalismo contemporâneo. A polêmica em torno ao caráter da IIRSA redunda, em última análise, em uma apreciação sobre o sentido das gestões presidenciais petistas no Brasil.

Ao romper com o escopo continental de propostas de integração regional pretéritas, a constituição da UNASUL e do NAFTA atestam, segundo Bethell, a inutilidade do conceito de América Latina na atualidade. Assim, o argumento do historiador inglês tem como premissa uma redução das possibilidades históricas de integração, assumindo como definitivos dois movimentos de integração regional em curso: um protagonizado pelos Estados Unidos que, a partir do estabelecimento do NAFTA em 1994, procura cimentar sua influência regional por meio de iniciativas em conluio com o estado mexicano, como o Plan Puebla-Panama, o Plan Merida e a ASPAN, ao mesmo tempo em que assina tratados bilaterais de livre-comércio com países da região, enfraquecendo as possibilidades de uma iniciativa latino-americana alternativa. Outro capitaneado pelo Brasil, substanciado em um projeto de integração sulamericana que ganhou corpo a partir da eleição de Lula em 2002 e recebeu expressão política mais elaborada com a constituição da UNASUL em 2008. A despeito da controvérsia sobre o sentido desta integração protagonizada pelo Brasil, podemos deduzir que uma iniciativa reunindo as antípodas políticas no subcontinente na atualidade, Colômbia e Venezuela, está mais próxima de ser uma organização "guarda-chuva", como advoga o Brasil, do que uma alternativa ao modelo neoliberal, como defendia Chávez (SANAHUJA, 2012), propositor, diga-se de passagem, da ALBA (Aliança Bolivariana para as Américas), como uma via de integração diversa e de escopo continental. De todo modo, considerando o caráter controverso destas iniciativas, endossá-las ideologicamente como faz Bethell, significa apoiá-las politicamente. O que, aliás, está em consonância com a posição do Departamento de Estado dos Estados Unidos, como revela este pronunciamento de Hilary Clinton em uma conferência da OEA em Lima no ano de 2010:

\section{GANPHLAC}

Revista Eletrônica da ANPHLAC, ISSN 1679-1061, №. 21, p. 261-297, Jul./Dez., 2016.

http://revista.anphlac.org.br 
Nós acreditamos que é do interesse nacional dos Estados Unidos e de todas as nações aqui representadas promover a colaboração pragmática e produtiva entre os membros da comunidade das Américas. É por isso que damos as boas-vindas a parcerias multilaterais como a UNASUL, o CARICOM e a SICA, e ao objetivo do Conselho Sul-Americano de Defesa (que é integrado a UNASUL) de promover uma maior confiança entre seus membros e uma cooperação mais efetiva para assegurar a segurança em relação ao crime organizado e ao terrorismo. (CLINTON, 2010)

\section{O Brasil na América Latina, ontem, hoje e amanhã}

Após resgatar as motivações na origem de um projeto de unidade continental, analisando a evolução histórica de seu conteúdo, retomarei o diálogo com a segunda proposição de Bethell, problematizando a pertinência de pensar o Brasil como parte de uma totalidade designada como "América Latina" no século XXI diante dos processos de integração regional em curso acima descritos.

Minha análise se baseará em três premissas subjacentes ao argumento desenvolvido até este momento. Primeiramente, saliento a historicidade do conceito de América Latina, apontando que seu significado e conteúdo político evoluem em consonância com o movimento da história continental. Por sua vez, o sentido deste movimento resulta de uma disputa política em que a dinâmica da luta de classes local e mundial se entrelaça. Em outras palavras, a vitalidade e o conteúdo político de um projeto de integração regional estão relacionados à correlação de forças entre as classes sociais em âmbito nacional e internacional. Assim, o panamericanismo de James Blaine está nas antípodas políticas da Nuestra América de José Martí, assim como a ALBA de Hugo Chávez se gestou em oposição explícita à ALCA de Bush, embora as quatro propostas expressem modalidades de integração regional. Como corolário das proposições anteriores, a atualidade do conceito de América Latina no Brasil e nos demais países do continente revela-se uma questão politicamente densa, relacionada não somente à leitura que se faz do movimento da história contemporânea e à correlação de forças entre os atores sociais, mas, sobretudo, ao horizonte civilizatório que se projeta para o continente. A implicação deste corolário é que entre a proposição de Bethell e a minha não há quem esteja

\section{GANPHLAC}

Revista Eletrônica da ANPHLAC, ISSN 1679-1061, №. 21, p. 261-297, Jul./Dez., 2016.

http://revista.anphlac.org.br 
certo ou errado abstratamente. $\mathrm{O}$ que se constata são premissas ideológicas diferentes que nos colocam, em relação a esta questão, em campos políticos opostos.

A partir destas considerações gerais que se aplicam a todos os países latino-americanos, resumirei minha leitura sobre a singular relação política e ideológica entre o Brasil e a América Latina nas linhas seguintes.

Vimos que o projeto de unidade continental foi avançado originalmente no contexto das guerras de independência hispano-americanas como um instrumento político visando afiançar a soberania dos novos países diante do risco de intervenção europeia. Ocorre que na emancipação do Brasil, em contraste com a América Espanhola continental, prevaleceu a negociação pactuada em lugar do confronto militar, de modo que o novo país vivenciou o paradoxo de ser governado por um príncipe português. Nesta conjuntura singular, o risco de uma intervenção europeia não esteve no horizonte político da monarquia escravocrata que se afirmou como bastião conservador no continente.

Em meados do século XIX, quando surge o conceito de América Latina em resposta às tensões decorrentes do expansionismo estadunidense na direção de México, América Central e Caribe, o Brasil tampouco tinha razões para temer a projeção continental de seu principal aliado na resistência às pressões inglesas pelo fim da escravidão, a despeito de projetos inconsequentes de anexação da Amazônia instigados por filibusteiros, nos moldes daqueles praticados ao norte do estreito de Darién (MONIZ BANDEIRA, 1998, p. 87-95).

$\mathrm{Na}$ virada do século (XIX-XX) a difusão das relações de produção capitalistas no contexto do imperialismo e a intervenção ianque na guerra de independência cubana, seguida de sucessivas invasões na região nos primeiros decênios do século, convergem para um "aggiornamento" da utopia de unidade continental, sempre em oposição aos Estados Unidos. Para além de pregadores incisivos, porém sem base social, como o argentino Manuel Ugarte, a repercussão das revoluções mexicana e bolchevique instigou a difusão de um sentimento antiimperialista, bem como do ideário comunista e do materialismo histórico em um contexto de aceleradas transformações socioeconômicas. Ressoando as reformas universitárias iniciadas em Córdoba em 1918 e a simpatia despertada pela resistência de Sandino na Nicarágua no final dos

\section{GANPHLAC}

Revista Eletrônica da ANPHLAC, ISSN 1679-1061, №. 21, p. 261-297, Jul./Dez., 2016.

http://revista.anphlac.org.br 
anos 1920, constituíram-se organizações referidas a um ideário latino-americanista em países diversos como Peru, Cuba e Argentina.

E o Brasil nesta conjuntura? No final do século XIX, o país já tinha produzido ao menos uma obra de destaque crítica aos Estados Unidos, o livro de Paulo Prado, A ilusão americana. Escrita à sombra da interferência ianque no episódio conhecido como a Revolta da Armada em 1893 que ameaçou o governo de Floriano Peixoto e a própria república, a obra está orientada pelo ideário monarquista, podendo ser classificada como reacionária e, evidentemente, não tinha como horizonte a integração continental. Longe de excepcional, este livro ilustra as dificuldades para se afirmar uma tradição política progressista em um país recém-egresso da escravidão e dominado pelo conservadorismo. É em reação a esta situação, que contrasta com outros países latino-americanos, que Antonio Candido reivindica um estatuto político transformador para aqueles que descreveu como intelectuais "radicais" no Brasil.

\footnotetext{
Pode-se chamar de radicalismo, no Brasil, o conjunto de idéias e atitudes formando contrapeso ao movimento conservador que sempre predominou. Este conjunto é devido a alguns autores isolados que não se integram em sistemas, pois aqui nunca floresceu em escala apreciável um corpo próprio de doutrina politicamente avançada, ao contrário do que se deu em países como o Uruguai, Peru, México e Cuba. (CANDIDO, 1990, p. 4)
}

Em minha opinião, é sobre este pano de fundo que devem ser apreciadas as visões sobre a América Latina produzidas no Brasil no início do século $\mathrm{XX}$, algumas das quais foram abordadas na tese de doutorado de Katia Gerab Baggio (BAGGIO, 1998). Chama a atenção que, entre os diversos intelectuais analisados, nenhum deles possuiu vínculo orgânico com um movimento que possa ser considerado como progressista. Aqueles que não estão no campo conservador aproximam-se da situação de "autores isolados que não se integram em sistemas" referida por Candido, como Manuel Bomfim ou Euclides da Cunha.

Assim, o limitado impacto do movimento pela reforma universitária que eclodiu em Córdoba em 1918 deve ser entendido como parte deste quadro geral: embora um abrangente estudo sobre o episódio identifique alguma repercussão no Brasil uma década mais tarde (PORTANTIERO, 1978, p. 18), materializada no movimento tenentista, o fato é que, em 1918,

\section{CANPHLAC}

Revista Eletrônica da ANPHLAC, ISSN 1679-1061, №. 21, p. 261-297, Jul./Dez., 2016.

http://revista.anphlac.org.br 
o Brasil simplesmente não tinha universidades ${ }^{7}$. Luis Carlos Prestes, expressão máxima da radicalização tenentista nos anos seguintes, aprofundou seu conhecimento sobre o marxismo na Argentina, ao final da épica empreitada que ficou conhecida com o seu nome, a "Coluna Prestes", na qual seus comandados percorreram parte do Brasil antes de se refugiaram em países vizinhos.

Como em outros países do continente, a percepção de que o Brasil partilhava de um legado histórico e de dilemas políticos comuns a seus vizinhos maturou em consonância com o processo de industrialização substitutiva de importações, que evidenciou, em uma palavra, o fenômeno do subdesenvolvimento. É a percepção da dimensão econômica da dependência, em um contexto em que a hegemonia geopolítica estadunidense se projeta ao sul do Canal do Panamá, que instiga a integração latino-americana como um horizonte político para o Brasil. O esgotamento da substituição de importações nos anos 1960 estimulou proposições de integração regional de motivação econômica, enquanto a repressão estatal apoiada pelos Estados Unidos aos movimentos de orientação democrático-nacional generalizou a dimensão política da solidariedade continental. Neste contexto, é significativo o número de intelectuais críticos brasileiros que pensam a América Latina, muitos dos quais foram também militantes exilados, como Celso Furtado, Florestan Fernandes, Darcy Ribeiro, Fernando Henrique Cardoso, Octavio Ianni, Rui Mauro Marini, Vania Bambirra, Theotonio dos Santos, entre outros.

O fim das ditaduras no Cone Sul nos anos 1980 significou uma democratização limitada, caracterizada por continuidades econômicas e sociais. A alternância política que sucedeu mal disfarçou os constrangimentos legados, intensificados com a difusão das políticas neoliberais no continente. Como decorrência, observou-se um desgaste generalizado de partidos tradicionais, abrindo espaço para a eleição de neófitos políticos (como Chávez na Venezuela; Morales na Bolívia; Correa no Equador; Lugo no Paraguai) ou para o triunfo de candidatos identificados com a oposição, como Tabaré Vazquez no Uruguai, Maurício Funes pela Frente Farabundo Martí em El Salvador e Lula da Silva no Brasil. A despeito das credenciais radicais

\footnotetext{
${ }^{7}$ A primeira universidade brasileira propriamente dita foi criada por iniciativa do governo federal no Rio de Janeiro em 1920, aglutinando as escolas Politécnica, de Medicina e de Direito já existentes. No âmbito estadual, em 1912, reuniram-se no Paraná a Escola de Engenharia, a Faculdade de Medicina e a Faculdade de Direito, dando origem à Universidade do Paraná.
}

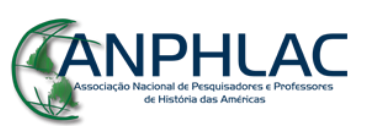

Revista Eletrônica da ANPHLAC, ISSN 1679-1061, №. 21, p. 261-297, Jul./Dez., 2016.

http://revista.anphlac.org.br 
de alguns destes líderes, prevaleceram governos nos marcos do que foi descrito como izquierda permitida (WEBBER; CARR, 2013, p. 5), caracterizados pela complacência em relação ao neoliberalismo, como é o caso das gestões petistas no Brasil. O ressurgimento de um projeto de integração subcontinental liderado pelo país neste contexto está marcado por ambiguidades na medida em que a materialização de uma proposta que reivindica este ideário, historicamente identificado com a soberania, tem reafirmado assimetrias regionais em lugar de amenizá-las, além de ter que contar com o aval declarado dos Estados Unidos.

Diante desta situação, relembramos que, do ângulo das correntes democráticas latinoamericanas, a integração regional não foi vista como um fim em si, mas como um meio para enfrentar a dupla articulação entre assimetria social e dependência externa. Nesta perspectiva, assim como um setor expressivo da sociedade mexicana não se resignou diante do NAFTA, os brasileiros que se opõem ao neoliberalismo devem denunciar qualquer modalidade de integração regional balizada pelos negócios, e não pela solidariedade entre os povos. Neste contexto, a afirmação de laços de identidade regional, em contraste com ideologias e estereótipos que reforçam o estranhamento, milita na segunda direção. A noção de que o Brasil faz parte da América Latina é parte deste embate.

\section{Conclusão}

Iniciamos este texto resgatando o contexto político e ideológico na origem da expressão “América Latina" com o propósito de deduzir as premissas que fundamentam a atualidade desta noção no século XXI. Indicamos que a pertinência do conceito está relacionada à integração regional como estratégia de inserção internacional, balizada pelo desígnio de assumir o controle sobre o tempo e o ritmo da mudança social no continente no contexto do imperialismo.

Portanto, quando Leslie Bethell afirma que o conceito de América Latina "seguramente perdeu a utilidade que talvez tenha tido alguma vez", inferimos que o historiador inglês considera desatualizada ou irrelevante a problemática que motivou sua origem, qual seja, a natureza assimétrica e predatória da relação entre os Estados Unidos e os demais países da

\section{GANPHLAC}

Revista Eletrônica da ANPHLAC, ISSN 1679-1061, №. 21, p. 261-297, Jul./Dez., 2016.

http://revista.anphlac.org.br 
região ${ }^{8}$. Esta é uma leitura política possível, embora contestada por uma ampla e plural tradição crítica latino-americana, que situa a questão do imperialismo - ou para usar os termos da CEPAL, as relações centro-periferia - no âmago da problemática do subdesenvolvimento.

Por outro lado, ao considerar que o sentido do termo América Latina se esvaziou desde que o México aderiu ao NAFTA e o Brasil orientou sua política externa na direção da América do Sul sob a égide da UNASUL, Bethell assume como dados processos políticos em curso e, portanto, objetos de disputa. Recordemos o levante zapatista em Chiapas em $1^{\circ}$ de janeiro de 1994, mesmo dia em que entrou em vigor o NAFTA, ou o plebiscito popular sobre a ALCA em 2002, ponto culminante de uma intensa mobilização social contra esta proposta no Brasil, e que incidiu no fracasso da iniciativa. Para aqueles que consideram irreversível os rumos da política mexicana, é pertinente lembrar que, embora os processos históricos não sejam reversíveis porque o próprio tempo não o é -, tampouco são inexoráveis. Para dar dois exemplos aleatórios, eram raros os franceses que, no começo do século XX, imaginavam uma Argélia independente, ou os soviéticos que vislumbraram o esfacelamento da União quando morreu Stálin. Nesta perspectiva, a naturalização de um contexto político em disputa revela-se como um procedimento intelectual antidemocrático na medida em que ignora o potencial de mudança social inerente à própria história, o que na era neoliberal remete à ideologia do fim da história.

Nesta perspectiva, reivindicar a atualidade do conceito de América Latina significa posicionar-se criticamente em relação às políticas que reafirmam uma inserção internacional da região subordinada aos Estados Unidos e que, como decorrência, reforçam a fragmentação continental, como é o caso do Plan Colombia, do NAFTA, dos Tratados de Livre Comércio assinados por diversos países em anos recentes, entre outros. De modo correspondente, sugerir que a noção de América Latina está ultrapassada justamente em função de políticas desta natureza, revela um empenho em transformar uma questão em disputa em um fato consumado, operação característica da ideologia e não do pensamento crítico.

\footnotetext{
${ }^{8}$ Esta leitura é coerente com a linha interpretativa de seus trabalhos, exemplificada em artigo sobre a Guerra do Paraguai em que desconsidera o papel dos ingleses como financiadores dos aliados, evidenciado no livro de Pomer, citado pelo próprio Bethell, cf. BETHELL, 1995; POMER, 1968. Sua perspectiva ideológica incidiu no critério de seleção dos colaboradores da História da América Latina que organizou para a Cambridge. Por exemplo, Fernando Novais conta que teve sua contribuição elaborada em parceria com Carlos Guilherme Mota rejeitada e substituída por um artigo do próprio Bethell. Este texto foi posteriormente publicado em NOVAIS; MOTA, 1996.
}

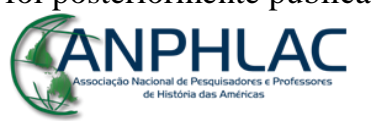

Revista Eletrônica da ANPHLAC, ISSN 1679-1061, №. 21, p. 261-297, Jul./Dez., 2016.

http://revista.anphlac.org.br 
Em outras palavras, se a noção de América Latina terá vitalidade conceitual em anos futuros é uma questão em aberto, a ser resolvida não na academia, mas sim no terreno da política, no qual os intelectuais tem um papel relevante, mas limitado. Afinal, há sempre o risco de que a teoria seja atropelada pela história. Pois, como ouvi de um militante do MST (Movimento dos Trabalhadores Rurais Sem-Terra), esqueceram-se de avisar o nosso pessoal que acabou a luta de classes.

Nesta perspectiva, a constatação de que a maioria dos brasileiros não se identifica com a América Latina, a respeito da qual sabem muito pouco, não deve ser interpretada como evidência natural da desconexão do país com sua região geográfica, mas antes como um indício de força do que Candido descreveu como o "movimento conservador" no Brasil. A mesma leitura se aplica às visões preconceituosas sobre os latino-americanos que prevalecem no senso comum. Devemos lembrar que as identidades nacionais e regionais são construções históricas, que se afirmam por oposição e se modificam no tempo.

Em sua trilogia sobre o orientalismo, Edward Said atenta para uma dimensão do discurso orientalista que caracteriza a sociedade contemporânea em que os meios de comunicação de massas expressam a hegemonia estadunidense, ou ocidental: os estereótipos que informam a produção e circulação de notícias sobre o mundo não europeu balizam a formação de opinião entre os próprios povos deformados por esta "cobertura", cujo caráter ideológico resulta em um "acobertamento". De modo análogo, entendo que o "descobrimento" da América Latina pelos brasileiros é e será uma construção política, justificada pelo desígnio de solidificar laços entre povos interessados em superar dilemas históricos comuns.

Longe de ser um fim em si, a integração latino-americana é entendida no campo democrático como um meio para proteger os interesses da comunidade continental dos efeitos destrutivos da concorrência intracapitalista em geral e da sanha estadunidense em particular. Nesta perspectiva, a identidade latino-americana pretende dissolver-se em um futuro em que a oposição aos Estados Unidos, que a define, se esvaziar. É o compromisso com este horizonte

\footnotetext{
${ }^{9}$ Daí o jogo de palavras no título de um dos livros de Said, Covering Islam, referindo-se ao "acobertamento" ideológico operado pelas coberturas jornalísticas sobre o tema no Ocidente (SAID, 1981).
}

\section{RANPHLAC}

Revista Eletrônica da ANPHLAC, ISSN 1679-1061, №. 21, p. 261-297, Jul./Dez., 2016.

http://revista.anphlac.org.br 
civilizatório alternativo acenado por José Martí, em que as identidades serão afirmadas não mais de modo adversativo, mas aditivo, que fundamenta a atualidade política do projeto de unidade continental.

\section{Referências Bibliográficas}

ANDERSON, Benedict. Imagined Communities. Londres: Verso, 2003 (1982).

ÁNGEL BARRIOS, Miguel. El latinoamericanismo en el pensamiento de Manuel Ugarte. Buenos Aires: Biblos, 2007.

ARDAO, Arturo. La idea de Latinoamérica. Montevideo: Semanario Marcha, 1282, 27 de noviembre de 1965 .

ARDAO, Arturo. Genesis de la idea y el nombre de América Latina. Caracas: Centro de Estudios Latinoamericanos "Romulo Gallegos", 1980.

ARICÓ, José. La hipótesis de Justo. Buenos Aires: Sudamericana, 1999.

AROSEMENA, Justo. Fundación de la nacionalidad panameña. Caracas: Fundación Biblioteca Ayacucho, 1982.

ARROYO PICARD, Alberto. México a 14 años del TLCAN: realidad y propaganda. In: Sandoval Palacios, Juan Manuel 2009. TLCAN: Balance general e impactos subregionales y sectoriales. (México: Red Mexicana de Acción frente al Libre Comercio). Disponível em: <http://www.rmalc.org.mx/documentos/libros/tlcan2009.pdf>. Acesso em 7/9/2013.

BAGGIO, Katia Gerab. A "outra" América: a América Latina na visão dos intelectuais brasileiros das primeiras décadas republicanas. (São Paulo) Tese de Doutorado, FFLCH-USP, 1998.

\section{GANPHLAC}

Revista Eletrônica da ANPHLAC, ISSN 1679-1061, №. 21, p. 261-297, Jul./Dez., 2016.

http://revista.anphlac.org.br 
BARTESAGHI, Lúcia; CERONI, Mauricio; DÍAZ, Ismael. Infraestructura Regional Sudamericana. Otro paso en la explotación de los pueblos y territorios sudamericanos. Montevideo: Programa Uruguay Sustentable Redes - Amigos de la Tierra, 2006.

BETHELL, Leslie (Org.). História da América Latina. São Paulo: EDUSP; Brasília: Fundação Alexandre Gusmão, 1997-2009.

BETHELL, Leslie (Org.). The Cambridge history of Latin America. Cambridge: Cambridge University Press, 1990-1999.

BETHELL, Leslie. O Brasil e a ideia de "América Latina" em perspectiva histórica. Rio de Janeiro: Estudos Históricos, v. 22, n 44, 2009.

BETHELL, Leslie. O imperialismo britânico e a Guerra do Paraguai. In: MARQUES, Maria Eduarda Castro Magalhães. A Guerra do Paraguai: 130 anos depois. Rio de Janeiro: RelumeDumará, 1995.

BOHÓRQUEZ Morán, Carmen L. Francisco de Miranda. Precursor de las independencias de la América Latina. La Habana: Editorial de Ciencias Sociales, 2003.

BRENNER, Robert. O boom e a bolha. Os Estados Unidos na economia mundial. Rio de Janeiro: Record, 2003.

CANDIDO, Antonio. Radicalismos. Revista do Instituto de Estudos Avançados, USP, v. 4, n. 8, jan./apr. 1990. Disponível em: <http://www.scielo.br/scielo.php?script=sci_arttext\&pid=S0103-40141990000100002 >.

Acesso em: 9 de março de 2011.

CARDOSO, Fernando Henrique; FALETTO, Enzo. Dependência e desenvolvimento na América Latina. Rio de Janeiro: Zahar, 1977 (1969).

CLINTON, Hillary Rodham, Secretary of State 2010. Address to the Organization of American States General Assembly. (Lima) 7 de junho de 2010. Disponível em: http://www.state.gov/secretary/rm/2010/06/142804.htm. Acesso em 20 de julho de 2011.

DESIDERA NETO, Walter; TEIXEIRA, Rodrigo. La recuperación del Desarrollismo en el Regionalismo Latinoamericano. Perspectivas para la integración de América Latina. Brasília: CAF; IPEA, 2012.

DEVÉS VALDÉS, Eduardo. Del Ariel de Rodó a la Cepal (1900-1950). Buenos Aires: Biblos, 2000.

\section{GANPHLAC}

Revista Eletrônica da ANPHLAC, ISSN 1679-1061, №. 21, p. 261-297, Jul./Dez., 2016.

http://revista.anphlac.org.br 
FERNÁNDEZ RETAMAR, Roberto. Pensamiento de Nuestra América. Buenos Aires: Clacso, 2005.

FERNÁNDEZ RETAMAR, Roberto. Todo Caliban. Buenos Aires: CLACSO, 2004.

FERNÁNDEZ, Teodosio. España y la cultura hispanoamericana tras el 98.In: ROYANO, Lourdes (Ed.). Fuera del olvido: los escritores hispanoamericanos frente a 1898. Santander: Servicio de Publicaciones de la Universidad de Cantabria, 2000.

FIRMIN, Joseph Antenor. De l'égalité des races humaines: anthropologie positive. Montreal: Mémoire d'encrier, 2005.

FURTADO, Celso. O mito do desenvolvimento econômico. Rio de Janeiro: Paz e Terra, 1974.

GALASSO, Norberto. Manuel Ugarte y la lucha por la unidad latinoamericana. Buenos Aires: Corregidor, 2001.

GOWAN, Peter. A roleta global. Rio de Janeiro: Record, 2003.

IIRSA. IIRSA 10 anos depois: Suas conquistas e desafios. Buenos Aires: BID - INTAL, 2011.

KLEIN, Naomi. A doutrina do choque: a ascensão do capitalismo de desastre. São Paulo: Nova Fronteira, 2008.

LA JUVENTUD ARGENTINA DE CÓRDOBA A LOS HOMBRES LIBRES. In: PORTANTIERO, Juan Carlos. Estudiantes y política en América Latina. 1918-1930. El proceso de la reforma universitaria. México: Siglo XXI, 1978.

LaFEBER, Walter. The New Empire. An Interpretation of American Expansion. New York: Cornell University Press, 1969.

LÖWY, Michael (Org.). O marxismo na América Latina: uma antologia de 1909 aos dias atuais. São Paulo: Perseu Abramo, 2003.

MARIÁTEGUI, José Carlos. Temas de Nuestra América. 11ª edição. Lima: Amauta, 1990.

MARINI, Ruy Mauro. Dialética da Dependência. Uma antologia da obra de Ruy Mauro Marini. Petrópolis: Vozes, 2000.

MARTÍ, José. Obras Escogidas. Tomo 2. La Habana: Editorial de Ciencias Sociales, 2000.

\section{CANPHLAC}

Revista Eletrônica da ANPHLAC, ISSN 1679-1061, №. 21, p. 261-297, Jul./Dez., 2016.

http://revista.anphlac.org.br 
MCGUINNESS, Aims. Path of Empire. Panama and the California Gold Rush. Ithaca: Cornell University Press, 2008.

MIGNOLLO, Walter. The Idea of Latin America. Oxford: Blackwell, 2005.

MONIZ BANDEIRA, Luis Alberto. Relações Brasil-EUA no contexto da globalização. I Presença dos EUA no Brasil. São Paulo: SENAC, 1998.

MOTA, Carlos Guilherme; NOVAIS, Fernando. A independência política do Brasil. $2^{\mathrm{a}}$ ediç̧ão. São Paulo: Hucitec, 1996.

NOLFF, Max C. (Org.). Desarollo industrial latinoamericano. México: FCE, 1975.

NOVOA GARZÓN, Luis Fernando. Brasil, via BNDES reforça caráter regressivo da integração latino-americana. (São Paulo) Entrevista ao Correio da Cidadania, 19/11/2011.

PHELAN, John L. El origen de la idea de Latinoamérica. In: Ideas en torno de Latinoamérica. México: UNAM/ Unión de Universidades de América Latina, 1986 (1965).

PINEDO, Javier. El concepto Segunda Independencia en la historia de las ideas en América Latina: Una Mirada desde el Bicentenario. Revista Atenea (Concepción), n 502, p. 151-177, 2010.

Plan del Partido Liberal en Díaz, Lilia. Planes políticos y otros documentos. Fuentes para la historia de la Revolución Mexicana. Prólogo de Manuel González Ramirez. 1ª reimpresión. México: FCE, 1974.

POLANYI, Karl. The great transformation: the political and economic origins of our time. Boston: Beacon Press 2001 (1944).

POMER, Leon. La guerra del Paraguay: gran negocio! Buenos Aires: Ediciones Caldén, 1968.

PORTANTIERO, Juan Carlos. Estudiantes y política en América Latina. 1918-1930. El proceso de la reforma universitaria. México: Siglo XXI, 1978.

PRADO, Eduardo. A ilusão americana. São Paulo: Alfa-Ômega, 2001 (1893).

PREBISCH, Raúl. O desenvolvimento econômico da América Latina e alguns de seus principais problemas. In: BIELCHOWSKY, Ricardo (Org.). Cinqüenta anos de pensamento na CEPAL. Rio de Janeiro: Record, 2000 (1949).

Programa da Unidade Popular (1970). In: CARLOS, Newton; FREITAS, Galeno de; VETTORI, Marcia. Chile com Allende, para onde vai? Rio de Janeiro: Gernasa, 1970.

\section{GANPHLAC}

Revista Eletrônica da ANPHLAC, ISSN 1679-1061, №. 21, p. 261-297, Jul./Dez., 2016.

http://revista.anphlac.org.br 
QUIJADA, Monica. Sobre el orígen y difusión del nombre 'América Latina' (o una variación heterodoxa en torno al tema de la construcción social de la verdad). Revista de Indias, 1998, vol. LVIII, n. 214, p. 595-616, 1998.

RODRÍGUEZ, Simón. Sociedades Americanas. Caracas: Biblioteca Ayacucho, 1990.

ROJAS MIX, Miguel. Bilbao y el hallazgo de América latina: Unión continental socialista y libertaria. Cahiers du Monde Hispanique et Luso-Brasilien-Caravelle, (Toulouse), n. 46, 1986, p. $35-47$.

SAID, Edward. Covering Islam. New York: Pantheon Books, 1981.

SANAHUJA, José Antonio. Regionalismo post-liberal y multilateralismo en Sudamérica: El caso de UNASUR. In: SERBIN, Andrés; MARTÍNEZ, Laneydi; RAMAZINI JÚNIOR, Haroldo. El regionalismo "post-liberal" en América Latina y el Caribe: Nuevos actores, nuevos temas, nuevos desafíos. Anuario de la Integración Regional de América Latina y el Gran Caribe 2012. Buenos Aires: Coordinadora Regional de Investigaciones Económicas y Sociales, 2012.

UGARTE, Manuel. La nación latinoamericana. Caracas: Biblioteca Ayacucho, 1987.

WEBBER, Jeffery; CARR, Barry. The new Latin American left. Cracks in the Empire. Lanham: Rowman \& Littlefield Publishers, 2013.

WILLIAMS, William Appleman. The tragedy of American diplomacy. Revised and enlarged edition. New York: Delta Book, 1962.

ZEA, Leopoldo. El pensamiento latinoamericano. Barcelona: Ariel, 1976.

ZEA, Leopoldo (compilador). Fuentes de la cultura latinoamericana. México: FCE, 1995.

\section{GANPHLAC}

Revista Eletrônica da ANPHLAC, ISSN 1679-1061, №. 21, p. 261-297, Jul./Dez., 2016.

http://revista.anphlac.org.br 